\title{
A MÁSCARA QUE SE DESFEZ EM GOTA D’ÁGUA
}

COSTA, Sueli Silva Gorricho ${ }^{1}$

Recebido em: $2008-08-30$

Aprovado em: 2009-03-27

ISSUE DOI: $10.3738 / 1982.2278 .139$

RESUMO: O presente trabalho teve como objetivo apresentar uma leitura da obra Gota d'água (1975), de Chico Buarque e Paulo Pontes. A finalidade é refletir sobre o valor do texto escrito, situado em um universo econômico, político, social e mítico, de uma sociedade desigual, sob um olhar literário.

Palavras-chave: Literatura, Obra Literária, Leitura, Século XX.

SUMMARY: This work aims to present a reading of Gota d'água (1975), by Chico Buarque and Paulo Pontes. The purpose of this research is to reflect about the value of written text, that is situated in an economical, political, social and mythical universe of a unequal society, under a literary view.

Keywords: Literature, Literary work, Reading, 20th Century.

\section{INTRODUÇÃO}

O presente trabalho tem como finalidade compreender o universo sócio-político, sob um olhar literário, em que se insere a obra Gota d'água, de Chico Buarque e Paulo Pontes.

O estudo é uma reflexão em que a consciência histórica busca em uma reescritura, Medéia, de Eurípedes, a totalidade do texto. Assim, expressa uma problemática moderna, adapta o antigo e faz uma peça nova e atual, que consiga atingir o espectador.

Essa análise é feita sobre o texto e não sobre o espetáculo. Considerou-se a posição de Aristóteles (apud BORNHEIM, 1969, p.33), que defende a independência do texto em relação ao espetáculo: "o efeito da tragédia não depende de sua representação por atores".

Bornheim (1969, p.33), diz que "nos tempos modernos, há a supremacia do texto

\footnotetext{
$1 \quad$ Prof $^{\mathrm{a}}$. Msc da Faculdade de Filosofia Ciências e Letras de Ituverava, dos cursos de Letras (Literatura Brasileira e Metodologia da Pesquisa Científica), Pedagogia (Literatura Infantil, Leitura, Interpretação e Produção de textos e Pesquisa em Educação) e Matemática (orientadora do estágio supervisionado).
} 
sobre o espetáculo, a tal ponto que os críticos passam a considerar, quase sempre, apenas o aspecto literário do espetáculo”.

Estreia em dezembro de 1975, no Rio de Janeiro, Gota d'água, de Chico Buarque e Paulo Pontes, baseada na idéia de Oduvaldo Vianna Filho. O discurso mítico decola num diálogo intertextual de Medeia, de Eurípedes, que ecoou da Antiguidade Grega e se fez canção em Gota d'água, que atualiza integrando as constelações econômico-político-sociais e míticas.

\section{Medeia, de Eurípedes: uma tragédia grega}

A tragédia original refere-se ao ciclo dos Argonautas. Iáson (Jasão) vai a Cólquida em busca do Tosão de Ouro. Medeia, feiticeira e filha do rei da Cólquida, apaixona-se por Iáson (Jasão), ajuda-o a obter a pele do carneiro sagrado e, depois de matar Pelias, o próprio tio, foge com Iáson para Corinto, torna-se sua esposa e tem com ele dois filhos. Tempos depois, movido pela ambição e já cansado da bárbara princesa, Jasão começa a se interessar pela filha de Crêon (Creonte), rei de Corinto, sendo plenamente bem-sucedido. Inicia-se então os preparativos para se casar com a nova princesa. Essa ingratidão, esse desprezo e abandono despertam os instintos selvagens de Medeia. Crêon, temendo que a fúria de Medéia se volte contra ele e sua filha, manda expulsá-la juntamente com seus dois filhos da cidade. Fingindo estar se preparando para partir, Medeia consegue adiar por um dia sua expulsão e aproveita esse tempo para matar Crêon e a filha; depois assassina os próprios filhos, preparando com a carne deles uma comida que serve a Iáson; em seguida, foge para Atenas, onde consegue asilo do rei Aigeus.

\section{Gota d'água: uma tragédia carioca}

Chico Buarque e Paulo Pontes entenderam o que havia de perene na peça de Eurípedes - a essência trágica do comportamento humano - e acrescentaram-lhe a tragédia que é a realidade dos tempos atuais. Em lugar de reis e princesas, Gota d'água

é povoada por miseráveis, malandros, macumbeiros, cantores populares, gigolôs e exploradores. Joana (nossa Medeia) é uma mulher madura, sofrida, que luta pela sobrevivência dos filhos, vive há anos com Jasão, dá-lhe roupas e joias e apoia a sua carreira de compositor e cantor de samba. Um dia, o rapaz acerta e compõe um sucesso musical intitulado Gota d’água. A música sobe em todas as paradas, é tocada em todas as rádios. Jasão fica famoso, aparece nos jornais, é idolatrado pelos fãs, entre os quais 
está Alma, filha do milionário e desumano Creonte, dono das casas da Vila do Meiodia, onde Jasão mora com Joana, rodeado por conhecidos e amigos de longa data. Creonte explora os miseráveis, aumentando constantemente as prestações das casas que muitos já não conseguem pagar. Deixa todos os moradores da Vila em suas mãos. Alma se apaixona por Jasão e o pai resolve apoiá-la. Corrompe Jasão que se torna o seu aliado na exploração dos miseráveis mutuários. Joana se desespera, luta, protesta contra o casamento de "seu homem", mas é obrigada a se retirar do conjunto habitacional. Na noite do casamento de Jasão e Alma, Creonte, não admite a presença dos filhos de Joana na festa e nem permite que sua filha Alma receba o presente que Joana lhe enviou, pois ele teme os "poderes de macumbeira" que Joana demonstra, com a sua crença e rebeldia. A única forma que Joana, inconformada, enlouquecida e desesperada, encontra de se vingar é envenenar-se com os dois filhos.

\section{O Século XX}

Para um melhor entendimento, deve-se levar em conta certos aspectos históricos e literários que serão norteadores desse trabalho.

O homem moderno sofreu grandes mudanças vividas pela sociedade com o processo de industrialização. Um processo desumano e pessimista que atingiu pessoas frustradas com a realidade, desesperançosas com o futuro, passivas, conformadas e nostálgicas.

Segundo Proença Filho (1988),

A presença do pensamento de filósofos como Nietzsche e Heidegger, [...] da
chamada corrente pós-estruturalista, entre cujos adeptos se encontram
Foucault, Jacques Derrida e Roland Barthes. Enquanto pensam, procuram
explicações, propõem soluções e apresentam idéias que propiciam mudanças
de comportamento [...], desenvolve-se a chamada sociedade de consumo.

Os produtos são valorizados mais pelo que eles apresentam ser e não pelo que são. A televisão passa a ditar modelos de comportamentos e influir na caracterização de mundo dos indivíduos. O computador passa a fazer parte do dia-a-dia das pessoas o que leva Proença Filho (op. cit p.37.) a dizer que "na verdade a configuração de um novo estágio do desenvolvimento tecnológico vem marcando a sociedade moderna".

Acentua-se a fragmentação social, o indivíduo perde para grupos representativos a sua participação política e passa a questionar os seus direitos e tomadas de posição. Isso acontece através dos movimentos feministas, homossexuais, dos negros e dos índios, que se tornam cada vez mais presentes. 
No cenário social e cultural, muitas mudanças aconteceram. Nas artes elimina-se a fronteira entre a arte erudita e a arte popular. Torna-se freqüente a presença da intertextualidade à luz das teorias de Bakhtin, do diálogo ou do cruzamento de vários textos. Na literatura contemporânea isso ocorre sobretudo com o aproveitamento intencional de obras do passado; mistura de estilos e preocupação com o presente, sem projeção no futuro.

Proença Filho (1988), diz:

Há um alto índice de politização e, de novo, a presença forte do nacionalismo. Entende-se melhor, diante desses fatos, que a literatura do período tenha-se voltado para o conhecimento e a expressão artística da realidade nacional, a partir de um posicionamento, sobretudo crítico [...] a tônica do Modernismo brasileiro envolveu a preocupação reflexiva com o Brasil, com a cultura brasileira e enriqueceu a linguagem literária[...].

$\mathrm{Na}$ literatura, intensifica-se o lúdico, o pastiche e a permanência da paródia. Usa-se a intertextualidade e a metalinguagem. Aparece no texto literário a figuração alegórica do tipo hiper-real e metonímico, como no pensamento de Benjamin (1984), em que a representação da realidade urbana é caracterizada através de elementos significativos e próximos, o que faz uma denúncia da realidade social. Acontece, também, o fragmentarismo textual (montagem cinematográfica), que lembra práticas dadaístas.

Quanto à questão da narrativa, Proença Filho (op. cit, p.44.) escreve: (que) ganha ênfase "o centramento na linguagem, ou seja, o privilegiar a linguagem como lugar de configuração do real".

Nesse espaço, a literatura passa a retratar aspectos relevantes da realidade social brasileira. O teatro intensifica suas conquistas e abre novas experiências. Algumas estabilizadas outras redimensionadas, mas carentes de pesquisa, estudo e reflexão.

\section{O contexto}

Nesse sentido, na obra Gota d'água, de Chico Buarque e Paulo Pontes, encontra-se uma representação da realidade urbana do Rio de Janeiro. Na ótica hiperrealista é uma denúncia da realidade social, em que o centro foi a classe média brasileira, representada pelo conflito de um marginal, Jasão, personagem da ficção, mas que remete à uma realidade realmente existente e comprovável até por notícias jornalísticas.

O texto busca mostrar essa realidade, menos metafórica, em que os personagens têm suas reflexões e suas preocupações existenciais. 
No prefácio de Gota d'água (BUARQUE; PONTES, 1975, p. xv), “a tragédia, é uma reflexão sobre esse movimento que se operou no interior da sociedade, encurralando as classes subalternas" (). O outro problema é cultural: "o povo sumiu da cultura produzida no Brasil - dos jornais, dos filmes, das peças, da televisão, da literatura, etc. Enfim, deixou de ser o centro da cultura brasileira. "(op.cit., p. xvi).

Entre esses aspectos, vale lembrar que o período compreendido entre 1950 e 1987, em que se insere a obra em questão, o Brasil vive acontecimentos políticos bastantes significativos e a população sem identidade, não se reconhece, mas ocupa o centro da realidade.

\section{A Literatura}

A arte sofre com a censura e, mesmo após esse período, as oscilações do poder, as implicações ideológicas, políticas e sociais influenciam nas criações literárias, embora não determinem nem expliquem a ação criadora. Isso se deve segundo Proença Filho (1988, p.51), “à autonomia, que desde o Modernismo, vem caracterizando a ação dos escritores brasileiros".

Para Pontes e Buarque (1975, p. xvii), “o fundamental é que a vida brasileira possa, novamente, ser desenvolvida nos palcos, ao público brasileiro. Nossa tragédia é uma tragédia da vida brasileira".

Essa preocupação reflete na forma da peça: era necessário evidenciar a volta da palavra, ou seja, dar voz àqueles que foram calados. Então, os autores preferem escrever a peça em versos, porque a poesia exprime melhor a densidade de sentimentos que move os personagens e tenta revalorizar a palavra.

Assim, essa obra é uma tentativa de reaproximação do teatro brasileiro com o povo brasileiro. Os autores vão encontrar em Medeia, de Eurípedes, os elementos dessa tragédia que queriam revelar.

Enquanto Medeia é uma história de reis e feiticeiros, Gota d'água é uma história de pobres e macumbeiros.

Coutinho (1997), diz

O passado literário é nosso conterrâneo. Mas, ao mesmo tempo, incorporando a tradição, os atuais modificam-na para criar o novo, enriquecendo-a com obras diferentes [...]. O passado só vale quando dele retiramos material útil para modelarmos nosso próprio sistema de normas e significados, e quando usamos o passado à nossa maneira. Ele deve inspirar-nos a ser presentes, a ser contemporâneos, e essa exigência implica o direito de aceitá-lo na sua diversidade, corrigi-lo ou rejeitá-lo. 
Portanto, a obra Gota d'água, mostra a inspiração dos autores em um texto histórico e artisticamente válido, Medeia, para criar, recriar e atualizar. Tudo isso ocorre em um processo de intertextualidade. É uma volta ao passado, mas atualizando-o ao nosso presente. Aceitam a sua diversidade, ou seja, a representação do gênero tragédia.

\section{O Gênero}

Segundo Abel (1968),
A tragédia além do fato dela nos tirar de encontro a uma realidade final: numa verdadeira tragédia ficamos além do pensamento. E por isso o autor de uma tragédia não tem de expressar idéias. Só tem de ter, como geralmente se diz, uma visão trágica da vida.

A personagem Medeia, se exila, mas não morre porque é tratada pelas leis que existem além dos deuses, enquanto Joana nada mais é do que a representação da classe oprimida, sofrida com a imposição da classe dominante.

Abel (op.cit) resume os valores e desvalores da tragédia:

\footnotetext{
A tragédia transmite de longe o sentido mais forte da realidade do mundo.

A tragédia florifica a estrutura do mundo, que supostamente reflete em sua própria forma.

A tragédia torna a existência humana mais vívida por deixar transparecer sua vulnerabilidade face o destino.

A tragédia pretende ser mediadora entre o mundo e o homem.

A tragédia deseja estar dos dois lados.

A tragédia não pode operar sem o pressuposto de uma ordem que seja um valor último.
}

A partir desses valores e desvalores relacionados à tragédia brasileira, em Gota d’água, percebe-se a preocupação clara com a questão de transmitir o sentido da realidade. É visível o poder no âmbito das classes sociais, pois há um domínio cada vez maior das classes dominantes, (que são) detentoras de estratégias argumentativas que visam criar efeitos de realidade e de verdade com o objetivo de convencer o oprimido.

A reflexão da estrutura do mundo, a vulnerabilidade da existência humana face o destino, mostra como o representante da classe dominante tem nas mãos o controle do poder, e que aqueles que representam a classe dominada são muitas vezes calados ou extintos.

Assim, como ser mediadora entre o mundo e o homem, ao mesmo tempo estar dos dois lados e não poder operar sem o pressuposto de uma ordem que seja um valor último? Gota d’água, mostra que a liberdade é mais uma das ilusões, em que o conflito 
entre o mundo e o homem impede a transformação. Isso ocorre porque o momento histórico é um momento obscuro para reflexões.

Segundo Noya Pinto (1989, p.70), “o abrandamento desta situação começou a se realizar no período de 1974-1979, período conhecido como da distensão, termo cujo sentido etimológico revela o grau de pressão vivido pela sociedade”. Essa sociedade pode ser representada como um eixo vertical, em que uns se localizam no espaço superior e outros no inferior.

Portanto, entre as obras que obtiveram êxito, depois do Modernismo, segundo Magaldi (1997), aparece Gota d'água, obra associada a um momento histórico, que na adaptação da tragédia Medeia, de Eurípedes, se fez canção.

Joana, não é uma mulher, mas sim a representação de várias mulheres que são humilhadas, trocadas e caladas por conta de uma sociedade ainda machista e opressora.

Do outro lado Jasão, aproveitador e individualista, que dispõe de um valor natural - a música, segundo Fiorin (1988), é o que garante a ascensão social, pois está aberta para todos os que dispuserem dos valores naturais de inteligência e vontade.

Creonte, o todo poderoso, o que manda e desmanda e que impõe a sua vontade sem dar aos outros o direito de escolha. Ele é o opressor e tem nas mãos o controle dos meios de produção mental. Esse tipo de autoridade, centralizada em uma autoridade (Creonte), assegura a manutenção do sistema, a concentração do poder e a circulação das rendas para pouco. É uma reflexão insuficiente, simplificadora, ainda perplexa do processo social para se constituir no traço dominante do perfil da vida brasileira.

Assim, a obra Gota d’água reflete em um processo de criação e recriação, a época em que foi escrita: um período em que a ditadura calava os homens com a censura e poucos se engajaram numa luta sócio-política. Bentley $(1969$, p.153) diz que "o engajamento, nada mais é do que um protesto contra a política que, por sua vez, constitui uma conduta política" .

No final da tragédia grega, Medeia é reconhecida como heroína pelos deuses e sai vitoriosa no carro do Sol. Joana não tem reconhecimento nenhum e vê como única saída de tanto sofrimento e humilhação apenas a morte:

Joana:

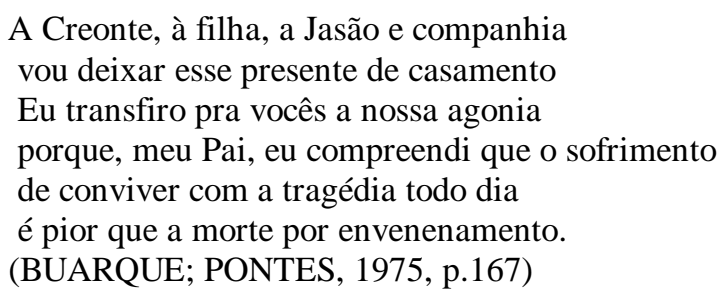




\title{
CONSIDERAÇÕES FINAIS
}

Para o filósofo Aristóteles (1993), a tragédia é:

\begin{abstract}
Imitação de uma ação de caráter elevado, completa e de certa extensão em linguagem ornamentada e com as várias espécies de ornamentos distribuídas pelas diversas partes (do drama), (imitação que se efetua) não por narrativa, mas mediante atores, e que, suscitando 'o terror e a piedade, tem por efeito a purificação dessas ações'. ${ }^{2}$
\end{abstract}

Sendo assim, a trama dos fatos compara a tragédia à história e analisa pontos teóricos particulares. $\mathrm{O}$ terror e a piedade que inspiram a tragédia, em Medeia, mostram a presença de certos elementos sobrenaturais que justificam certos fatos.

Já em Gota d’água, é a realidade de uma sociedade desigual, com abuso de poder, em que os mais fracos nada mais são do que pessoas oprimidas, caladas e que aprenderam a conviver com a tragédia todo o dia e jamais terão o reconhecimento pelo seu valor humano.

São as decisões de poucos que moldam o destino de muitos e se faz canção, ainda que seja uma canção como a Gota d'água.

\section{REFERÊNCIAS}

ABEL, L. Metateatro: uma visão nova da forma dramática. Rio de Janeiro: Zahar editores, 1968.

ARISTÓTELES. Poética. 2 ed. São Paulo: Ars Poética, 1993.

BENTLEY, E. O teatro engajado. Rio de Janeiro: Zahar, 1969.

BORNHEIM, G. A. O sentido e a máscara. 2 ed. São Paulo: Perspectiva, 1969.

BUARQUE, C.; PONTES, P. Gota d’água. São Paulo: Civilização Brasileira, 1975.

COUTINHO, A. A literatura no Brasil: relações e perspectivas - conclusão. 4 ed. são Paulo: Global, 1997.

EURÍPEDES, Medéia. In: Teatro de Eurípedes: Hipólito, Medéia, As Troianas. Trad. direta do grego, introdução e notas de Mário da gama Kury. Rio de Janeiro: Civilização Brasileira, Brasília: INL, 1977.

FIORIN, J. L. O regime de 1964: discurso e ideologia. São Paulo: Atual, 1988.

MAGALDI, S. Panorama do teatro brasileiro. 3 ed. São Paulo: Global, 1997.

NOYA PINTO, V. Comunicação e cultura brasileira. 2 ed. São Paulo: Ática, 1989.

PROENÇA FILHO, D. Pós-Modernismo e literatura. São Paulo: Ática, 1988.

2 (Poet. VI, 27 - trad. E. Souza)

Nucleus, v.6, n.1, abr. 2009 